\title{
Political Islam (The Justice and Development Party in Turkey) Versus the Gülen Movement
}

\author{
Dr. Recep Dogan \\ Wisdom College, Brisbane, Australia \\ 97 Formby Street, Calamvale, QLD, Australia \\ Tel: 61-403-000-982Ｅ-mail: drdogan66@gmail.com
}

Received: March 2, 2018 Accepted: May 10, 2018 Published: May 12, 2018

doi: 10.5296/jsss.v5i2.13126 URL: http://doi.org/10.5296/jsss.v5i2.13126

\begin{abstract}
Islam has been interpreted by individuals since its birth and Political Islam is one of them. Moderate Muslim Scholars have identified some of its interpretations as extreme due to their consequences and negative effects on Muslims and others. Political Islam has a long history and the Justice and Development Party (the AKP) is a new face of it in $21^{\text {st }}$ Century. The purpose of this paper is to explore the defining political Islam, especially in the characteristics of the Ruling Party (Justice and Development Party) and compare its Islam to Hizmet (service) Movement. Although the AKP has long benefitted from the valuable support of Fethullah Gülen and his followers in the way of democratizing the state and its institutions the two allies have clearly separated from each other since 2013 maybe a little bit earlier. This separation has created a massive impact on Muslims as well as on other people. Due to a great polarization, hatred and enmity between the two groups and its huge effect on society it has become a necessity to analyze the interpretation of Islam by these two groups.
\end{abstract}

Keywords: Political Islam, the AKP the Justice and development Party, Gulen Movement, the Hizmet, Recep Tayyip Erdogan, Fethullah Gülen

\section{Introduction}

Islam is an important element which shapes social, political, and economic life in Turkey as well as in other parts of the Muslim world (Samuel, 1993). By manipulating and misinterpreting Islam and its key concepts the AKP has obtained a massive political power and justified its authoritarianism and antidemocratic approaches in the state (Yeşilada, 2016). The continuous political success in the elections in Turkey has led the Justice and Development Party (the AKP) to be more exclusive towards other groups. Because, the main 
goal for the AKP is achieving super power in political arena through reviving caliphate and uniting Muslims under its banner (Maessen, 2012). Opposing to Gülen's mentality Erdogan and his political party AKP have started to use harsh language to anyone or any group who criticize them (Yilmaz \& Bashirov, 2018a). This is why the AKP have become intolerant and authoritarian to the Hizmet Movement sympathizers.

In 2013, a group of young individuals protested the AKP government for environmental concerns and it turned into an opposition movement against the party (Sarikaya, 2016). Erdogan's government reacted them harshly and this attitude escalated the protests. Although, during the protests the Gülen movement did not support the protestors nor the government the AKP perceived it as opposition to itself (Yilmaz \& Bashirov, 2018a).

Initially, the Gülen movement supported the Justice and Development Party (the AKP) in Turkey to democratize the state. However, since December 17-25, 2013 corruption investigation against the Justice and Development Party the differences in the mentality of each group and their Islamic understanding has clearly emerged.

In 2013, a general prosecutor of Turkish Justice System issued an arrest order for 50 Turkish officials on the basis of a serious corruption. The suspects of the corruption were accused of bribery and of the illegal transfer of gold to Iran through the state-owned bank Halkbank (Istanbul Hurriyet, 2014). The corruption allegations caused to the resignation of several key figures in the AKP's government (Istanbul Hurriyet, 2013). Minister of environment and urban planning Erdogan Bayraktar declared to the press that for the sake of the well-being of this nation and country, I believe the prime minister should resign. (Istanbul Hurriyet, 2013). Indeed, the leaked wiretaps recorded calls between Erdogan and his son Bilal suggested that they were also involved in the corruption (Yilmaz \& Bashirov, 2018a).

Turkey witnessed a political crisis around corruption accusations. Instead of investigating the allegations and proving its innocence or cleaning the guilty ones from the government and party, Erdogan accused Fethullah Gülen and his sympathizers as a counter attack. His government immediately changed the work places of thousands of policemen all over in Turkey and dismissed many on the basis of accusation that they were Gülen sympathizers (Solaker, 2014). But, there were not a single evidence proving thousands of officials were form the Gülen movement. Nevertheless, Erdogan changed the public attention from the serious corruption allegations to the movement.

Although the corruption case was prepared by officials in conformity with the law the AKP government did not accept it for it may undermine its legitimacy. Moreover, the Hizmet or Gülen movement become a victim of political persecution by Erdogan government. Furthermore, Erdogan publicly called for a witch hunt against the Gülen sympathizers and this caused persecutions of thousands by the government. Many of the Hizmet sympathizers have been dismissed, detained and arrested;

Since the outbreak of the corruption scandal, Erdogan and his government has been targeting Gülen movement and according to security officials, around more than 200, 000 individuals have been dismissed, 124,257 detained, 57,885 sent to jail from all walks of life including 
businessmen, doctors, teachers, academics, police officers, philanthropists and even housewives (The Fountain Magazine Special Issue, 2017).

Hate speech by Erdogan and the AKP against the Gülen sympathizers has become a daily routine (Yilmaz \& Bashirov, 2018a). Moreover, they have been struggling very hard to discredit the movement in the other parts of the world to make sure its biggest enemy does not survive at all (Yilmaz \& Bashirov, 2018a). Erdogan and his government consider the Hizmet movement as the biggest threat for their political power. Because, opposing to other religious groups, this movement did not give Erdogan pledge of alliance to support his caliphate (Marsili, 2016).

When Political Islamists controlled the government and consolidated their power by continuous success in elections in Turkey they have not hesitated to reveal their real identity which is destroying all opponents and establishing monopoly in the power (Marsili, 2016). Indeed, this was the main reason for the Gülen movement to break its ties with the AKP (Demiralp, 2016). The Hizmet movement clearly rejected antidemocratic approaches of the AKP, thus, became the main target which needed to be eliminated. The differences in the ideology, worldview and interpretation of Islamic sources have caused dramatic split between the Hizmet and the AKP (Political Islam) eventually. The deep differences in each group came to be known over time and the split between them became inescapable. This separation turned into one of the fiercest political battles in the history of Turkish politics (Gursel, 2013).

Through controlling and manipulating the executive and legislative power in the state the AKP aims to eradicate Hizmet movement and its followers. In this regard, the government shut down all the schools, universities, hospitals, media outlets etc. established by Gülen sympathizers and put thousands of them in jail (The Fountain Magazine Special Issue, 2017). It seems, political Islamists will continue to remove any opposition -whether possible or actual threat to their ideology- to secure its political power. All antidemocratic practices by AKP since 2013 proves this hypothesis.

Although some may argue that the clash between the AKP government (political Islamists) and the Gülen movement was a power struggle within the state, but, it does not tell the real story. The most effective cause that split the two groups from each other was directly related to their understanding of Islam or in other word, how each group interpreted Islam in theory and practice. Thus, the split between them in reality was the difference between political Islam and Hizmet interpretation of Islam.

\subsection{The Gülen or Hizmet Movement}

Hizmet Movement is a civic community which aims to serve humanity through education and the dialogue between religions and cultures (Çetin, 2010). Sympathizers of this movement are inspired by the teachings of Fethullah Gülen who is a Muslim scholar and community leader (Esposito \&Yilmaz, 2010). Gülen has been preaching moderate Islam and universal human values since his young age. He advocated intercultural and interfaith dialogue to promote peace in the world (Hendrick, 2013). Although he teaches Islamic values he does not seek to 
establish an Islamic state as a political entity (Öktem, 2011). Because, this only increases hatred, enmity and polarization in the world.

The movement has carefully maintained their distance from active politics and political parties (Yavuz, 2003). Nevertheless, the sympathizers of this movement have obtained positions in various state institutions, therefore, the movement has been accused by the AKP as taking over the government secretly. The reasonable logic in the ideology of Hizmet and its acceptability by people from various cultures, ethnicities and faith groups have given an opportunity for the movement to spread out quickly all over the world through establishing schools and cultural institutions. Inspired by the ideology of Gülen, businessmen, teachers and dedicated youth immigrated to countries all over the world (Çetin, 2010). They did not experience much hardships in spite of its massive expansion for they focused on universal human values rather than religious concepts.

Opposing to a common assumption, Gülen inspired schools follow a secular education in conformity with host country authorities, rather than Islamic education (Aydin, 2011). They offer a modern multilingual education to their students. Scientific disciplines are encouraged in these schools. Without imposing their ideology to others, teachers try to apply good manners in their personality. They try to educate children in the schools on the basis of universal values with the expectation that they could contribute to world peace, social harmony and interfaith dialogue (Aydin, 2011).

\subsection{Political Islam}

Islam is a religion which offers a set of rules to its followers in relevance to their individual, familial, social and governmental life. The interpretation of Islam by individuals, nations and cultures is different than Islam itself for it can be interpreted in many different ways. Political Islam is a particular form of interpretation which aims to establish a political structure (Fuller, 2003). The supporters of this ideology desire to create an Islamic state which is governed by the Sharia.

Political Islam stands for the ideology that Islam as a body of faith has something important to say about how politics and society should be ordered in the contemporary Muslim world and who seeks to implement this idea in some fashion (Fuller, 2003). It pursues political objectives and provides political responses to today's problems by concepts borrowed from the Islamic tradition (Denoeux, 2002). Nevertheless, Political Islam is not independent of particular social and political contexts in which appears.

Today, the advocators of political Islam are rigid minded radicals who aim to implement the sharia in political sense. They are not open to make political compromises. Thus, its ideology is anti-democratic as it can be seen in the representation of the AKP. According to the ideology of political Islamists, the caliph, the head of Muslims, represents God's sovereignty and everyone must obey him. They use democracy as an instrument to come to power. But, once in power they give all power to one person.

Ibn Taymiyya, the Hanbali theologian (1223-1328), argues that the essence of government is applying force to people so they live in obedience and their solidarity is not ruined (Ibn 
Taymiyya, 1983). Thus, the ruler can demand obedience from his people, even if he is not just, because, an unjust ruler is better than turmoil and the disunity of society (Ibn Taymiyya, 1983). It is obvious that ibn Taymiyya advocates political order rather than justice and individual rights. This approach opened the way for the dictators to legitimize their authoritarian rule.

Political Islam has a long history. It has appeared in various forms as a reaction to a ruler, or to a society, or to political conditions. Since it is very difficult to cover all the history of Political Islam and its various forms we mainly focused on the Political Islam that has emerged in the last decades.

Initially, Western colonialization in the Middle East and other parts of the Islamic world caused some Muslim leaders/groups to conceptualize Political Islam as a response to the west. They advocated the notion of political power, caliphate and unity of Muslims to protect Islam and Muslim world (Charles, 2000). Thus, Political Islam was a reaction to western state model (Laclau, 1990).

The colonialization of Islamic lands has led scholars to seek solutions. Some scholars identified the problem as the clash of two conflicting state models and developed the solution accordingly. Others saw the problem as the fight between the west and the east. In general. Muslim scholars tried to develop some responses to protect Muslim identity against the west. Instead of understanding the real problems that have caused Muslims to set back scholars have offered some weird ideologies including the political Islam. Moreover, Political Islamists argued that they could ignore the rest of the world for they did not need to learn/take anything from the infidels (Lewis, 2000).

In order to achieve political objectives individuals or groups use Islam in a political sense. Islam is like an instrument for political Islamists to achieve their targets. However, it is impossible to accept one style which would be the same in all political Islamic theories. Every political Islamic theory is subject to particular social and political contexts in which religious groups operate (Hourani, 1983).

Although political Islamists desire to implement the sharia they may easily contradict basic Islamic teachings in their daily life due to their extreme interpretation of Islam. More than $\% 90$ percent of Islam is related to personal practice and it can be applied without having an Islamic state (Gulen, 2005). It is a great contradiction to advocate political aspect of Islam before practicing majority of it in daily life. In this regard, Australia, America and many European countries are much better in terms of allowing individuals to practice their faith. Opposing to this, Muslims countries such as Saudi Arabia, Turkey, Iraq, Syria and Tunisia do not give much freedom to their citizens to practice their religion as they wish, especially when the interpretation of Islam is different than state's one.

Political Islamists do not believe in liberal democracy for it is against God's sovereignty. However, they use democracy until attaining political power as it can be seen in the AKP example. They believe that every means in the way of obtaining political power and monopoly in the state is permissible. In this regard, they interpret the Sharia according to 
their extreme ideology and makes it permissible to use force, apply violence and practice anti-democratic implementations to secure their political power. They use religion and its concepts as an instrument to cover up their corruption and justify their violence. For example, the AKP and Erdogan put thousands of innocent people in jail to cover up their corruption and consolidate their political power. Obviously, Islam never permits violence, wrong doings and injustices no matter what the reason would be.

\section{The Rise of Political Islam in Turkey}

In 1923, Mustafa Kemal Atatürk implemented a revolution by military force to westernize the state (Ergil, 2000). With the aid of military, he imposed a secularist vision on Muslim society. He tried to cut the connections with the Ottoman past. Atatürk and other secularist elites in the state carried out a series of reforms such as abolishing the caliphate to cut Turkey's ties to its Islamic past (Ergil, 2000). They shut down religious institutions and secularized the education system. Although religion was banished from the public sphere it could not be completely eliminated, rather, this attitude caused to develop a hidden Islamic identity within the secularist state (Yavuz, 2000).

After the abolishment of the caliphate, a number of religious groups struggled for power. Each had its unique approach to save the country and offered solutions to citizens. One of these groups was political Islamists. They knew that Islam had major effect on population, thus, they maintained that if they could articulate Islamic political theory well they would obtain political power. In this regard, they championed the idea that Islam could only be practiced properly in a state governed by the Sharia.

In the meantime, the secular state did not want autonomous groups to develop outside of its control for it was a potential threat to modernization of the state (Yavuz, 2000). Trying to shape the society through force and oppression the secular state alienated the large majority of population (Toprak, 1988). In response to antidemocratic practices of the state, political Islamists aimed to provide political voice to Muslim society. Over time, they developed their own goals and ideology in the secular state.

The establishment of a multiparty system in 1946 was an important turning point in the rise of political Islam in Turkey (Rabasa \& Larrabee, 2008). The secular elites lost their monopoly on political power. Moreover, parties in Turkey had to recognize Muslim identity in order to attract votes from the society. In 1960s, Democrat Party (Demokrat Parti - DP) legitimized Islam and its values to be successful in the political arena (Rabasa \& Larrabee, 2008). However, the Turkish military attempted a coup and created the National Security Council (MGK) to impose its secular ideology on politicians (Toprak, 1988). In the meantime, the US began a policy of supporting political Islam in the Middle East as a counter attack to the Soviets' influence. During this time, political Islamists managed to form their own separate political party under the leadership of Necmettin Erbakan, a professor of engineering. Erbakan's MSP (National Salvation Party) made considerable gains in the 1973 elections, receiving 11.8 percent of the vote and becoming a key party in the formation of a coalition government in Parliament (Özkan, 2015). Between 1973 and 1980, the MSP formed coalition governments with parties the Nationalist Action Party and the Mainland Party (Özkan, 2015). 
In the secular state, all Islamic parties were under pressure. They were banned or closed down on several occasions. With negative experiences, the advocators of Political Islam improved their ideology and reemerged in various guises to increase their durability. Despite the restrictions and exclusions of Islam from politics, religion and religious identity has played an important role in Turkish Political Islam (Ergil, 2000).

Erbakan established the Welfare party (Refah Partisi) in 1983 and returned to political arena once again. Turkey enjoyed religious and economic freedom under the ruling of Prime Minister Turgut Özal. During his time, religious groups had opportunity to establish their own private schools and universities (Rabasa \& Larrabee, 2008). This also opened up a political space for the followers of political Islam (Mardin, 2007).

The fight between Turkey's Islamists and the Turkish state began again in 1996, continued through the February 28 coup in 1997 and its aftermath. The secular state understood that it was impossible to eradicate Muslims from the political arena in Turkey, thus, changed its approach towards political Islam and wanted to use it to design the Turkish politics, economy and social life instead of destroying it.

\subsection{The Justice and Development Party and Rise of Political Islam in Turkey}

In the early 1990s, Political Islamists achieved a success in political arena by winning 19 percent of the vote and the mayor's office in 28 municipalities (Yeşilada, 2016). They obtained the political success by focusing on social issues rather than religious themes. However, the secular elite and the military felt great anxiety because of their success in political arena. Moreover, Erbakan, the leader of political Islamists started to advocate the Sharia and criticize the secular system. He openly stated that the sharia will come back to Turkey, but, the only question was whether it would be bloody or not (Ergil, 2000).

Instead of reducing social tensions, Erbakan and political Islamists polarized Turkish society, therefore, the National Security Council presented a list of recommendations to them on February 28, 1997 (Gunay, 2001). Eventually, the leader of Political Islam had to resign in 1997 due to post-modern coup and the Welfare Party was closed down in 1998 (Gunay, 2001).

The military and secular elites imposed on society that religion could not be used to consolidate the nation. Political Islamists understood that they could not succeed in political arena by open agenda. They rethought their future political strategy through intense internal debate. The debate divided political Islamists into two groups; the "traditionalists" (Gelenekçiler), centered on Erbakan and "reformists" (Yenilikçiler), led by Recep Tayyip Erdoğan, the mayor of Istanbul (Rabasa \& Larrabee).

The reformists argued that they need to change their approach towards democracy, human rights and other core issues. They founded a new party, Justice and Development Party (Adalet ve Kalkinma Partisi, the AKP), with the leadership of Erdogan. The new party or the new form of political Islam acted as if it was open to cooperation with the democracy and the west. Until obtaining monopoly in power the AKP emphasized on democracy and the rule of law. It advocated the membership in the EU to reduce the influence of the military as well as 
to consolidate its own power (Mardin, 2007).

There were a number of reasons for the AKP elites, the new political Islamists, to place a strong emphasis on democracy and EU membership. They certainly understood that if they did not respect secularism they would not survive and participate in the Turkish political system effectively (Öniş, 2006). They also needed the West and democracy to defend themselves against the secularist elites in the state institutions especially in the military. In order to naturalize the power of the military in Turkish politics, political Islamists (the AKP) regarded the EU as natural ally (Dağı, 2006).

Initially, in order to attract more voters from the country Erdogan and the AKP did not use Islamic slogans, rather they stressed on common themes. They cooperated with secular elites, thus, received complements from many scholars. They got appreciation with their ability to harmonize Islam with democracy. Realizing the advantages of this strategy, the AKP declared its priority as economic progress, the EU membership, democracy and human rights (Dağ1, 2006). They cooperated with the IMF, advocated the centrality of NATO and partnership with the United States (Öniş, 2006). Moreover, they declared Israel as an important partner to Turkey's national security. In reality, this was a new political strategy which political Islamists developed after the tragic end of the previous party.

By hiding its real face and true agendas with sophisticated tactics the AKP has won elections since 2002 to present. Even when Erdogan was a mayor he stated that democracy was like a streetcar, you would use it until you reached your destination (Öniş, 2006). He believes that a state cannot be a secular for Muslims should have an Islamic state.

Erdogan has grown increasingly authoritarian. He has oppressed the media and restricted freedoms. He has shot down 184 media outlets including STV, Bugun TV and Zaman national newspaper (The Fountain Magazine Special Issue, 2017). He controlled the judiciary by appointing his loyalists to this institution. He destroyed separation of powers in the state. He has started to use slogans increasingly nationalist and Islamist. The ultimate political goal for Erdogan is an authoritarian state in which the caliph (himself) exercises his super power without being held accountable (Yilmaz \& Bashirov, 2018a).

\subsection{The Comparison Between the Hizmet Movement and Political Islam}

The AKP benefitted from democracy until it gained a strong power in the state institutions. Now, it does not hide its anti-democratic ideology and practices. So, democracy or democratic approach was a trick used by political Islamists to deceive the secularists, the west and even Islamic movements of Turkey which supported the AKP believing it will democratize the state.

Erdogan deems every method permissible to achieve his political targets. Even, as a political strategy he stayed in prison for three months in a luxury conditions to convince society that he was persecuted due to his political opinions, thus, Turkish nation should support him in his fight against secular system. After getting rid of secularists and Turkish military he has started to use religious concepts and Islamic slogans. He demonstrated the Quran at public rallies during the June 2015 electoral campaign (Yeginsu, 2015). He often would begin his 
remarks with Quranic citations to promote political Islam (Yeginsu, 2015).

The continuous success revealed the real face of the AKP. It started to pursue a more aggressive and authoritarian form of political Islam. Indeed, from the very beginning of their political party establishment, they aimed to achieve full control of the governmental institutions. Erdogan's ambition to appoint administrators, judges, and university rectors is no longer a secret (Yilmaz \& Bashirov, 2018a). He had a hidden agenda to change Turkish society with Wahhabi form of Islam, now it is clear and obvious. Although Turkish form of Islam is more moderate as it can be seen in the interpretation of Gülen, the AKP and Erdogan chose Wahhabi form of Islam to consolidate their political power.

Opposing to the AKP and Erdogan, Fethullah Gülen and the Hizmet movement stayed away from politics and political Islam. They focused on education. They strongly reject the notion of political Islam. In this regard, they stand out compared to most religious communities in Turkey for many reasons. Firstly, they do not oppose the west, rather they believe that if any civilization produced any common value for humanity Muslims should benefit from it. Secondly, they support the European Union, human rights, democratic values and the secular education. Thirdly, they are against racism for they believe that all human beings are created by God, thus, each of them deserves love, respect, compassion and dialogue. Indeed, the acceptability of Gülen movement by people from different cultures, faith and nationalities is mostly related to its approach towards all human beings.

Although Gülen movement isolated themselves from Turkish politics the AKP and Erdogan declared them as their enemy due to the party's desire to obtain monopoly in political power. Apparently, Erdogan assumed the Gülen movement as just another religious community which would obey his antidemocratic interests. But, the movement did not obey him. Thus, Erdogan waged a war against Gülen and his sympathizers to secure the way towards the super-presidential system of government.

The representatives of the movement have been persecuted severely, yet, they seek their rights through democratic ways without resorting terror and violence. Ironically, Erdogan accused the movement with terror, but they never resorted violence and terror in spite Erdogan's government illegally seized their properties, shut down their schools, dismissed hundreds of thousands from their jobs, put thousands of them in jail including women with their little children and elder ones who are in their eighties.

Erdogan argues that Turkey needs a super-presidential system of government in order to make himself an untouchable sultan (Yilmaz \& Bashirov, 2018a). The ambition of Erdogan to super powerful presidency has increased the tension in Turkish politics. Moreover, he has created a tremendous fear on society that if anyone opposes him he/she ends up in jail (Yeşilada, 2016).

It is obvious that now Turkish politics is defined by Erdogan and religious groups which are loyal to him. Erdogan has close relations with religious groups, divinity schools, Directorate of Religious Affairs and other effective elements in Turkish politics to secure the way towards the super powerful presidential system. He aims to control religious groups and 
religious affairs in Turkey (Yeginsu, 2015). In this regard, he has collaborated with religious scholars, community leaders, religious groups and Directorate of Religious Affairs (The Diyanet).

Although people from the Gülen movement never resorted any violence or terror, even when they were persecuted so heavily, Erdogan and the AKP declared Gülen and his sympathizers as a terrorist group. In order to support Erdogan's extreme accusation Directorate of Religious Affairs (the Diyanet) issued a religious statement (fatwa). Mehmet Gormez, the ex-head of Diyanet, declared the Hizmet Movement as a deviated sect and millions of its followers as infidels (The Diyanet, 2017 "Dini İstismar Hareketi FETÖ/PDY Raporu." The Diyanet, June 26. http:/gaihl.meb.k12.tr/tema/icerikler/din-isleri-yuksek-kurulu-baskanligi-tarafindan-hazirlan an-dini-istismar-hareketi-fetopdy-raporu_3464700.html). With this fatwa (religious verdict) he justified all the injustices and persecutions done by the AKP government against the Gülen sympathizers.

The Diyanet, a religious institution which is supposed to speak according to criteria of the Qur'an and Sunnah, has become a political tool of Erdogan. One of the basic principles of Islam is that it is not permissible to declare a Muslim group as deviated sect. Moreover, it is strongly prohibited to declare any Muslim as infidel. According to basic Islamic teachings anyone who declares the testimony "there is no god but Allah and Muhammad is His Messenger" is accepted as a Muslim (Muslim, 1994) and no one can call him/her as infidel. No institution has authority to declare a Muslim as an infidel (Ibn Abidin, 2013). Although Prophet Muhammad warned Muslims stating, "insulting a Muslim is an evil action and fighting him/her is disbelief," (Muslim, 1994) radical groups and political Islamists ignored this type of clear religious texts and declared many Muslims such as the followers of Gülen Movement as infidels (The Diyanet, 2017).

There is a strong similarity between the terror groups such as ISIS and Directorate of Religious Affairs (the Diyanet) with regards to labeling other Muslims as infidels and then legitimizing all kinds of evils against them. Under the rule of AKP the Diyanet has become more radical and extreme. By interpreting the Islamic sources according to demands of Erdogan, the Diyanet only contributes the radicalization process of Turkish people and worsens the problem. Currently, too much polarization, hatred, enmity and divisions among people in Turkey and there seems no solution for it in the near future. At this stage, the Diyanet takes active part to spread enmity among the different segments of Turkish society by misinterpreting the religious sources and supporting violence by their extreme fatwas (The Diyanet, 2017).

The people from Gülen Movement have been known as moderate Muslims since decades. They have been serving in 170 countries for all humanity to promote peace, harmony and mutual understanding in the world (Esposito \&Yilmaz, 2010). Especially, they worked very hard to raise moderate Muslim generations in Turkey who are away from radicalism and extremism.

Gülen has produced more than 70 books in Turkish and most of them are translated into many 
languages including English. His books usually get appreciation from people who are from different cultures and backgrounds (Michel, 2005). Many academics have been working on his books and ideas. Some universities have opened chairs dedicated to his name. If Gülen and the Hizmet Movement have any extreme tendency or inclination towards violence and terror it would have been known for he and the Hizmet Movement are well known by many academics and other people all over the world. Since its beginning to present time no one proved that Gülen or any of his sympathizers involved in violence or terror to promote their ideology. Opposing to this, many academics from different nations have appreciated the movement due to its great service to humanity and its moderate Islamic understanding (Michel, 2005).

Although Erdogan accused Gülen movement with terror there are strong allegations that Erdogan himself supports Salafi radical terror organizations. It is argued that Erdogan's government supports radical terror groups in Syria and Iraq by smuggling ISIS oil to Turkey and arming terrorist groups in the country (MacIntyre, 2015). US Senator Richard Black claimed that Turkey supports terrorists in Syria, not only by sending weapons, but also by providing logistical, financial and intelligence support for them (Phillips, 2016).

Nowadays, political Islamists and radical terror groups, such as the AKP and ISIS, have been using the concept of jihad in their campaign to promote their radical approach. With the deceptive usage of this term, they want to obtain support from pious Muslims all over the world. On the other hand, Gülen refutes this extreme approach by explaining jihad's various meanings in different contexts. He defines jihad as one's struggling against all destructive emotions (Gulen, 1998). Gülen sees radical groups and political Islamists as a real threat for the entire world, and therefore openly rejects their claims on the basis of primary Islamic sources (Gülen, 2014. Weekly Lectures. Retrieved from, http://www.herkul.org/weekly-sermons/the-grave-consequence-of-murders-committed-underthe-guise-of-religion-2/).

Opposing to Erdogan, Gülen stated that "a real Muslim who understood Islam in every aspect could not be a terrorist" (Gulen, 2005). He stressed on the fact that terrorism must be condemned without any excuses. He even labelled the suicide bombers as the companions of hellfire. Gülen deems terrorism as the greatest blow to peace, democracy, and humanity and he always condemns any terrorist activity irrespective of whom it is carried out by, or for what purpose it is done (Gulen, 2004).

\section{Political Islamists and Their State}

The idea of establishing an Islamic state looks attractive today to Muslims who have been persecuted by internal tyrannical regimes. The hope for a better future in terms of religious freedom, expression of Muslim identity and other human rights are used by extreme groups and politicians for their political agendas. Establishing an Islamic state is mixed with a call for a return to the Shari'ah. Islamic state is preeminently a Shari'ah state, defined by its commitment to a vision of legal order (Brown, 1997). In other words, the call for an Islamic state is the call for the establishment of Islamic law and the caliphate. However, the very word Shari'ah conjures images of social control through severe criminal punishments. 
Political Islamists and the AKP invoke the religious texts and certain historical precedents of Islamic government to prove the idea of establishing an Islamic state. They want to preserve the close link between religion and politics that the traditional jurisprudence had developed. They maintain that religion and politics cannot be separated for they both together create the notion of Islamic State.

In order to achieve his target with regards to establishing an Islamic state Erdogan needs support of religious scholars and their fatwas (juristic opinion or religious verdicts). In this regard, I will give a few examples from Professor Hayrettin Karaman who has been very close to Erdogan and also who articulates the extreme mentality of political Islamists (Kuru, 2016). Hayrettin Karaman (1934) is a professor of Islamic Law who has long been supporting the AKP Government and Erdoğan against the opposition parties and groups by his fatwas and interpretations of Islamic rules in accordance with the benefit of the AKP/Erdoğan (Kentel, 2016).

Political Islamists believe that the AKP is the only party which truly represents Islam, thus, it is a religious duty for each Muslim to vote for AKP (Yilmaz, 2018b). Karaman argues that Erdogan and the AKP are doing jihad, thus, he even supported them in the scandalous corruption probe of December 17-25 by producing religious fatwas in which he misinterpreted Islamic rules in favor of political Islamists (Karaman, 2014a). He argued that the Muslim leader (Erdogan) can get bribes in the form of $10 \%$ or $20 \%$ commission from businessmen and companies, because, this is legally likened to the share of 'alms collectors' in the early years of Islam (Karaman, n.d.). The logical reasoning for his fatwa (religious verdict) is that the money is needed for promoting Islam (Yilmaz, 2018b).

Another extreme fatwa given by Karaman is that individuals and religious communities can also be sacrificed for the sake of the state (Karaman, 2013). With this fatwa he legitimized all the evil acts done against the followers of Gülen Movement. He argued that the Movement worked against the state and its Muslim ruler, thus, it was a religious duty to destroy it. Because, preventing division among Muslims and protecting the state are religious duty, thus, it is permissible to apply all kind of pressure to destroy the movement. For example, he implied that Ihsan Yilmaz, a professor and Research Chair in Islamic Studies and Intercultural Dialogue at Deakin University, had become an apostate due to his speech against the AKP and Erdogan (2014b). This approach is very similar to ISIS and al Qaeda terrorist groups who declare their opponents as apostates and then kill them brutally.

The last extreme fatwa of Karaman was related to the referendum on the amendment of Turkey's Constitution held on April 16, 2017, which led to the opening of gates for Erdogan to super powerful presidential system (Yilmaz, 2018b). Erdogan stated that a devout Muslim should vote Yes, otherwise they go to hell. Thereupon, Karaman supported Erdogan's extreme ideology with his extreme fatwa; "a yes vote is an Islamic obligation" (Yayla, 2017). He argued that in order to make Turkish state an Islamic state all Muslims must support Erdogan by voting 'Yes' in the referendum (Karaman, 2017).

After all these examples, it can be speculated that Turkey has becoming an Islamists' state in a rigid sense under the rule of Erdogan with the support of extreme religious scholars such as 
Karaman and their extreme fatwas. Indeed, Karaman has adopted the extreme mentality of terrorist groups by labeling all opponents as apostates. He legitimized all kind of evils against anyone or any group who oppose Erdogan and who do not give pledge of allegiance to the caliph (Erdogan). The persecutions and injustices done against the Hizmet prove the extreme mentality of Political Islamists and Erdogan. I personally believe that Political Islamists and its leader Erdogan are more dangerous than contemporary terrorist groups. Because, although terrorist groups such as ISIS and Al Qaeda remain marginal among Muslims Political Islamists and Erdogan receive a great support in Islamic world in spite of their extreme mentality. It will not be wrong to argue that Political Islamists will be the biggest treat for the world peace in near future by promoting its extreme ideology and radicalizing the youth, especially in the west.

\section{Conclusion}

The Justice and Development Party's (the AKP) success in Turkish politics was a historic victory. For a long time, Turkish people were dominated and oppressed by secular elites who were foreign to Turkish Islamic culture. The AKP, the representative of Political Islam in Turkey, achieved all these successes with the expectation from society that it could democratize the state and recognize the rights of every citizen. Although the Justice and Development Party (the AKP) promised eradication of corruption it was heavily involved in the biggest corruption scandal in Turkish history.

Instead of bringing democracy to the state, Erdogan and political Islamists started to advertise the Sharia, the notion of Islamic state and revival of caliphate. Because, Erdogan has autocratic whims to consolidate his power and destroy all of his opponents. According to his ideology, everything is permissible in the way of achieving the desired target. In order to obtain absolute power, he deems permissible any form of pressure, restrictions on human rights and even persecution of opponents. Erdogan and political Islamists believe that they can rightfully loot the properties of their enemies and take their wives as their concubines on the basis of their distorted interpretation of Islam.

Opposing to Erdogan and political Islamists, Gülen and his sympathizers (the Hizmet movement) represent a moderate Islam. They rejected Erdogan's extreme form of Islamic interpretation and stood against his antidemocratic ambitions and the desire for to be the caliph of Muslims. They publicly criticized political Islam, the ideology of Erdogan and his political party. Moreover, they refuted their extreme interpretation of Islam -political Islamwith the teachings of the Qur'an and Prophet Muhammad.

In conclusion, the impact of fight between Erdogan and Gülen or political Islam and the Gülen movement will be felt for decades to come on Turkish society and politics. The future of Turkey is strongly related with the result of the fight between the two groups. If political Islamists win their fight against Gülen movement Turkey will become Paradise for all radical and extreme groups in the Middle East. Opposing to this, if the Hizmet movement succeeds in its opposition to Erdogan and political Islamists Turkey would have become a role model for all Muslim countries with regards to combining Islam with liberal democracy, human rights, freedom, interfaith dialogue and good relations with the west and with all people all 
over the world.

\section{References}

Al-Qushayri, M. I. H. (1994). Sahih Muslim. Fadail Sahabah, Beirut: Dar al-Ma'rifah Publishing.

Aydin, H. (2011). The Educational Effectiveness of Gülen-inspired Schools: The Case of Nigeria. Ph.D. Dissertation Thesis, Reno: University of Nevada.

Brown, N. (1997). The Rule of Law in the Arab World: Courts in Egypt and the Gulf. Cambridge: Cambridge University Press. https://doi.org/10.1017/CBO9780511583278

Bukhari, M. I. I. (1997). Al-Jāmi' Al-Sahih. Riyadh: Darussalam Publishers and Distributors.

Çetin, M. (2010). The Gülen Movement: Civic Service Without Borders. New York, NY: Blue Dome Press.

Charles, C. A. (2000). Islam and Modernism in Egypt. London \& New York: Routledge.

Dağı İ.D. (2006). "The Justice and Development Party: Identity, Politics, and Human Rights Discourse in the Search for Security and Legitimacy", in The Emergence of a New Turkey: Democracy and the AK Parti, edited by M. Hakan Yavuz, Salt Lake City: University of Utah Press.

Demiralp, S. (2016). The Breaking up of Turkey's Islamic Alliance: the AKP-Gülen Conflict and Implementations for Middle East Studies. Middle East Review of International Affairs, 20, pp. 1-7.

Denoeux, G. (2002). The Forgotten Swamp: Navigating Political Islam. Middle East Policy, 9, 56-81. https://doi.org/10.1111/1475-4967.00057

Ergil, D. (2000). Identity Crises and Political Instability in Turkey. Journal of International Affairs, 54, 43-62.

Esposito, J. L., \&Yilmaz, I. (2010). Islam and Peace-building: Gülen Movement Initiatives. New York, NY: Blue Dome Press.

Fuller G. (2003). The Future of Political Islam. New York: Palgrave. https://doi.org/10.1057/9781403978608

Gülen, F. (1998). Asrın Getirdiği Tereddütler (Questions and Answers about Islam). İzmir: Nil Yayınlari.

Gunay, N. (2001). Implementing the 'February 28' Recommendations: A Scorecard. Washington Institute for Near East Policy Retrieved from http://www.washingtoninstitute.org/policy-analysis/view/implementing-the-february-28-reco mmendations-a-scorecard

Gursel, K. (2013). AKP-Cemaat Savasinda Neyi Savunmalıyı? (What Should We Defend in the AKP-Cemaat War?) 
Hendrick, J. D. (2013). Gülen: The Ambiguous Politics of Market Islam in Turkey and the

World. New York: New York University Press. https://doi.org/10.18574/nyu/9780814770986.001.0001

Hourani, A. (1983). Arabic thought in the Liberal Age, 1798-1939. New York: Cambridge University Press. https://doi.org/10.1017/CBO9780511801990

Huntington, S. (1993). Clash of Civilizations. Foreign Affairs, 72, 22-25. https://doi.org/10.2307/20045621

Ibn Abidin, M. I. U. (2013). Rad al-Mukhtar. Riyadh: Markaz al-Turath lil-Barmajiyat.

Ibn Taymiyya, T. (1983). Kitab as-Siyasa. Beirut: Dar al-Afaq al-Gadida,

Istanbul, Hurriyet. (2013). Environment Minister Bayraktar Announces Resignation, Calls on PM Erdoğan to Quit.

Karaman, H. (2013). Türkiye'nin dostları ve düşmanları. Retrieved from http:/www.yenisafak.com/yazarlar/HayrettinKaraman/turkiyenin-dostlari-ve-dusmanlari-444 56

Karaman, H. (2014a). Yolsuzluk başka hırsızlık başkadır.

Karaman, H. (2014b). Doğru mu yalan mı?

Karaman, H. (2017). Neyi oyluyoruz?

Karatnycky, A. 2002. Muslim Countries and Democracy Gap. Journal of Democracy, 13, 99-112.

Kentel, F. (2016). The right to the city during the AK Party's thermidor. In U Cizre (Ed.), AK Party and its leader: criticism, opposition and dissent (pp. 132-165). Routledge, London and New York.

Kuru, A. T. (2016). Sharia, Islamic ethics, and democracy: the crisis of the Turkish model. In R. Hefner (Ed.). Sharia law and modern Muslim ethics (pp. 170-188). Indiana University Press, Bloomington. https://doi.org/10.2307/j.ctt2005t30.11

Laclau, E. (1990). New Reflections on the Revolution of Our Time. London: Verso.

Lewis, B. (2000). The Muslim Discovery of Europe. London: Phoenix Press.

Maessen, J. M. A. H. (2012). Reassessing Turkish National Memory: the AKP and the Nation. An analysis of the representation of Turkish national memory and identity by the AKP. Master Thesis, Faculty of Humanities, Utrecht University.

MacIntyre, S. (2015). Turkey's informal ISIS support. Retrieved from http://torontosun.com/2015/11/19/turkeys-informal-isis-support/wcm/907b9a54-efae-41e3-8e dc-ef3beaa04617

Mardin, Ş. (2007). Turkish Islamic Exceptionalism Yesterday and Today: Continuity, Rupture and Reconstruction in Operational Codes. Turkish Studies, 6, 45-165. 
https://doi.org/10.1080/14683840500119478

Marsii, M. (2016). The Islamic State: A Clash within the Muslim Civilization for the New

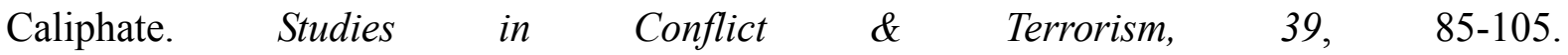
https://doi.org/10.1080/1057610X.2015.1100010

Michel, T. (2005). Sufism and Modernity in the Thought of Fethullah Gülen. Muslim World, 95, 341-358. https://doi.org/10.1111/j.1478-1913.2005.00098.x

Öktem, K. (2011). Turkey since 1989: Angry Nation. London: Zed Books.

Öniş, Z. (2006). The Political Economy of Turkey's AKP. In The Emergence of a New Turkey: Democracy and the AK Parti, edited by M. Hakan Yavuz, Salt Lake City: University of Utah Press.

Özkan, B. (2015). Turkey's Islamists: From Power-Sharing to Political Incumbency. Spring, $14,71-83$.

Phillips, D. L. (2016). ISIS-Turkey Links. Retrieved from https://www.huffingtonpost.com/david-1-phillips/research-paper-isis-turke_b_6128950.html

Rabasa, A., \& Larrabee, F. S. (2008). Political Islam in Turkey. National Defense Research Institute, Santa Monica: RAND Corporation.

Sangasari, B. (2014). Tayyip Erdoğan's Leaked Phone Calls. Retrieved from https://www.youtube.com/watch?v=3TIAQm89x_8

Sarikaya. A. (2016). Erdogan and the Presidential System, Cultural Relations Quarterly Review, 3, 22-28.

Solaker, G. (2014). Turkish ruling party MP slams government in resignation, police purged. Retrieved

from https://www.reuters.com/article/uk-turkey-corruption/turkish-ruling-party-mp-slams-governm ent-in-resignation-police-purged-idUKBREA0U19420140131

The Diyanet (Turkish Directorate of Religious Affairs). (2017). Dini İstismar Hareketi FETÖ/PDY Raporu. Retrieved from http://gaihl.meb.k12.tr/tema/icerikler/din-isleri-yuksek-kurulu-baskanligi-tarafindan-hazirlan an-dini-istismar-hareketi-fetopdy-raporu_3464700.html

The Fountain Magazine. (2017). What Went Wrong with Turkey. The Foundation Special Issue, New Jersey: Blue Dome Press.

Toprak, B. (1988). The State, Politics and Religion in Turkey. In State, Democracy and the Military in the 1980s Turkey, edited by Metin Heper and Ahmet Evin. Berlin \& New York: Walter de Gruyter.

Yavuz, H. (2000). Cleansing Islam from the Public Sphere. Journal of International Affairs, $54,21-42$.

Yayla, A. S. (2017). Turkish referendum: when democracy falls short of a majority. 


\section{Macrothink}

Journal of Social Science Studies

ISSN 2329-9150 2018, Vol. 5, No. 2

Yeginsu, C. (2015). Turkey's Elections Will Test Power of the President. Retrieved from https:/www.nytimes.com/2015/06/04/world/europe/turkey-elections-recep-tayyip-erdogan-k urds-hdp.html

Yeşilada, B. A. (2016). The future of Erdoğan and the AKP. Turkish Studies, 17, 19-30. https://doi.org/10.1080/14683849.2015.1136089

Yilmaz, I., \& Bashirov, G. (2018a). The AKP After 15 Years: Emergence of Erdoganism in Turkey, Third World Quarterly.

Yilmaz, I. (2018b). Potential Impact of the AKP's Unofficial Political Islamic Law on the Radicalisation of the Turkish Muslim Youth in the West.

\section{Copyright Disclaimer}

Copyright for this article is retained by the author(s), with first publication rights granted to the journal.

This is an open-access article distributed under the terms and conditions of the Creative Commons Attribution license (http://creativecommons.org/licenses/by/3.0/). 